\title{
Knowledge of Member Farmers about Farmers Interest Group (FIG) under ATMA
}

\author{
Mugdha Ninama ${ }^{1 *}$ and Arun Patel $^{2}$ \\ ${ }^{I}$ Department of Extension Education, BACA, AAU, Anand, Gujarat, India \\ ${ }^{2}$ Major Guide-Retd. DEE, AAU, Anand-388110 \\ *Corresponding author
}

\section{A B S T R A C T}

Keywords

Knowledge, Member of farmers interest group

Article Info

Accepted:

10 January 2021

Available Online:

10 February 2021
Knowledge is defined as body of understood information possessed by an individual. In this study knowledge is conceptualized as body of understood information possessed by FIG group member about FIG under ATMA. One of the leading features of ATMA is formation and strengthening of FIG for farmers to farmers approach. Knowledge is one of the important components of behavior and as such plays an important role in the covert and overt behavior of an individual. Keeping the above definition in view, an attempt has been made to study the knowledge of member farmers about Farmers Interest Group under ATMA. The result of study revealed that slightly less than three fourth (73.50 per cent) of FIG members had a high level of knowledge about the Farmers Interest Group, followed by 17.50 per cent,7.00 per cent and 2.00 per cent had medium, very high and low level of knowledge about Farmers Interest Group. None of them had very low level of knowledge about Farmers Interest Group.

\section{Introduction}

ATMA focused on a bottom-up planning process in order to make the entire extension system farmer-driven and farmer accountable. This has helped to strengthen research and extension capabilities, restructure public extension services and test new institutional arrangements for technology transfer with the involvement of all the stakeholders of Government and Non-Governmental agencies at the district level. ATMA represents a unique institutional platform that aims to integrate at the district level the weakly linked research and administration arms of publicsector agricultural extension in India.

The key institution in implementing this new approach was the ATMA which was responsible for facilitating and coordinating "farmer-led" extension activities within each district. One of the leading features of ATMA 
is formation and strengthening of FIG and organizing Farm School for farmers to farmers approach.

Research in India about FIG on various aspects carried out by Hingonekar (2011), Munni (2016), Kumar and Rathakrishnan (2017), Lal (2007) and Patel et al., (2018), revealed that the knowledge of farmers about FIG confined to medium level. Knowledge is generally understood as an intimate acquaintance of an individual with facts. Knowledge as a body of understood information possessed by an individual or by a culture. In this study knowledge is conceptualized as body of understood information possessed by FIG group member about FIG under ATMA. Keeping the above facts in view, an attempt has been made to study the knowledge of member farmers about Farmers Interest Group under ATMA.

\section{Materials and Methods}

The current investigation was carried out in Anand district of Gujarat state. For the study where fairly good numbers of Farmers Interest Groups were available, two talukas namely Anand and Umreth were purposively selected. The list of animal husbandry based FIGs working in Anand district had been collected from the Project Director, ATMA, Anand.

\section{Selection of respondents}

From the selected two talukas, Anand taluka has total 54 Animal Husbandry based FIGs and Umreth talukas has total 55 Animal Husbandry based FIGs. Total 40 FIGs were selected by proportionately random sampling, 20 FIGs from Anand taluka and 20 FIGs from Umreth taluka were selected by lottery method of sampling. Then after, 5 farmers were randomly selected from each of the selected FIG. Thus in all 200 farmers who are the member of FIG were selected for the study.

\section{Measurement of level of knowledge}

The knowledge of member farmers about Farmers Interest Group was studied by using developed test. The FIG members were asked to state correct answer among options of questions. The score was given according to the response of their answer. 'Zero' score was assigned for wrong answer and 'One' score for right answer.

Finally, the scores on all questions in the knowledge test for each of the FIG members were summed up and the level of knowledge about FIG was worked out. The maximum obtainable score was 28 and minimum was 0 .

In order to determine the overall level of knowledge about Farmers Interest Group, the FIG members were categorized into the following five categories by using arbitrary method of classification:

\section{Results and Discussion}

The knowledge of member Farmers about Farmer Interest Group was studied by using developed test. The data regarding knowledge of member Farmers about Farmers Interest Group are presented in [Table 1] and graphically depicted in [Fig-1].

The data given in Table 2 stated that slightly less than three fourth (73.50 per cent) of FIG members had a high level of knowledge about the Farmers Interest Group, followed by 17.50 per cent,7.00 per cent and 2.00 per cent had medium, very high and low level of knowledge about Farmers Interest Group.

None of them had very low level of knowledge about Farmers Interest Group. To epitomize the results, it can be said that the overwhelming majority (91.00 per cent) of respondents had high to medium level of knowledge about Farmers Interest Group. 
Table.1

\begin{tabular}{|c|c|c|}
\hline No. & Category & Score range \\
\hline $\mathbf{1}$ & Very low & Up to 5.60 \\
\hline $\mathbf{2}$ & Low & 5.61 to 11.20 \\
\hline $\mathbf{3}$ & Medium & 11.21 to 16.80 \\
\hline $\mathbf{4}$ & High & 16.81 to 22.40 \\
\hline $\mathbf{5}$ & Very high & 22.41 to 28.00 \\
\hline
\end{tabular}

Table.2 Distribution of the respondents according to their level of knowledge about farmers interest group

\begin{tabular}{|c|c|c|c|}
\hline No. & Knowledge & Frequency & Percent \\
\hline $\mathbf{1}$ & $\begin{array}{c}\text { Very low } \\
\text { (Up to 5.60) }\end{array}$ & 00 & 00.00 \\
\hline $\mathbf{2}$ & $\begin{array}{c}\text { Low (5.61 } \\
\text { to 11.20) }\end{array}$ & 04 & 02.00 \\
\hline $\mathbf{3}$ & $\begin{array}{c}\text { Medium } \\
(11.21 \text { to } \\
\text { 16.80) }\end{array}$ & 35 & 17.50 \\
\hline $\mathbf{4}$ & $\begin{array}{c}\text { High }(16.81 \\
\text { to 22.40) }\end{array}$ & 147 & 73.50 \\
\hline $\mathbf{5}$ & $\begin{array}{c}\text { Very high } \\
(22.41 \text { to } \\
28.00)\end{array}$ & 14 & 07.00 \\
\hline & Total & 200 & 100.00 \\
\hline
\end{tabular}

Fig.1 Distribution of respondents according to their level of knowledge about farmers interest group

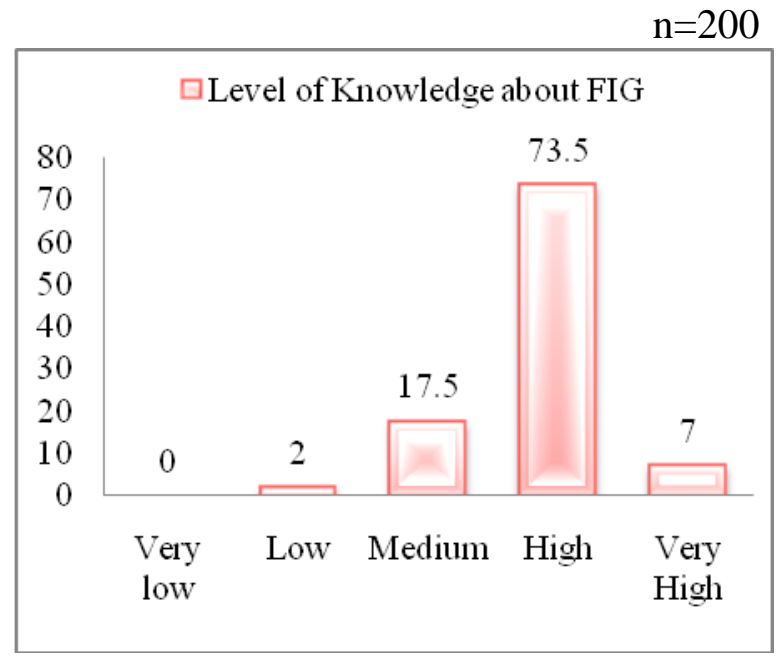


Formation of field specific animal husbandry based Farmers Interest Groups (FIGs) has been highly beneficial to farmers. After realizing the benefits of FIGs, the member farmers were more active in participation and meetings. The member farmers who participated in every extension oriented programmes had gained knowledge and adopted new technologies. This might be the reason for improvement in their knowledge about FIGs. The Findings are more or less in line with the results of study conducted by Patel, et al., (2016), Chaudhary and Chauhan, (2016) and Christian, et al., (2015).

From the above study it can be said that the overwhelming majority (91.00 per cent) of respondents had high to medium level of knowledge about Farmers Interest Group.

\section{Application of Research}

The findings of the study will facilitate in knowing the existing knowledge of member farmers about Farmers Interest Group. It will help them in planning and implementing efforts to develop and spread knowledge of FIG more effectively.

\section{References}

Chaudhary, D and Chauhan N.M. (2016) Knowledge and Adoption of Biofertilizer Users. Guj. J. Ext. Edu., 27(2), 177-179.

Christian, B.N., Chauhan, N.B. and Macwan, A.R. (2015) Knowledge of Farmers
Regarding Wheat Production Technology. Guj. J. Ext. Edu., 26(2), 219-222.

Patel, G.J., Patel, D.P. and Ramjiyani, D.B. (2016). Knowledge of nutritional practices among the tribal women. Guj. J. Ext. Edu. Vol. 27(1), 24 to 26.

Lal, B. (2007). Role of Common Interest Groups (CIGs) in Empowerment of Dairy Farmers: A comprehensive study in Rajasthan. National Dairy Research Institute Karnal. Ph.D. (Unpublished) Thesis.

Hingonekar, S. S. (2011). Role perception and role performance of FIGs working under ATMA project at Tapi and Valsad districts of South Gujarat. M. Sc. (Agri.) thesis (unpublished), NAU, Navsari.

Kumar, M. R. and Rathakrishnan, T. (2017). Diagnosing socio-personal characteristics of Farmers Interest Group members of Guava in Tamilnadu. Journal of Inter Academiciai. 21(4):470-473.

Munni, K. (2016). Information seeking behaviour about animal husbandry enterprise holders of Farmer's Interest Groups of Navsari district. M. Sc. (Agri.) thesis (unpublished), NAU, Navsari.

Patel, J. B., and Chauhan, N. B., and Vinay Kumar, H. M. (2018). Relationship between attitude of farmers towards FIG and their profile in Anand district of Gujarat. Gujarat. J. Extn. Edu. 29(2):174-177.

\section{How to cite this article:}

Mugdha Ninama and Arun Patel. 2021. Knowledge of Member Farmers about Farmers Interest Group (FIG) under ATMA. Int.J.Curr.Microbiol.App.Sci. 10(02): 1430-1433. doi: https://doi.org/10.20546/ijcmas.2021.1002.171 